\title{
Makedonien - kostbar kitsch og dyb krise
}

\section{Af Anne Haubek}

Det er ikke så ofte, begivenheder i Makedonien når de internationale medier, men i forbindelse med forårets voldsomme uroligheder - de værste siden 2001 - har der igen været overskrifter om 'frygten for at krudttønden på Balkan skulle eksplodere igen'.

"Vi ses i hovedstaden for kitsch og korruption!" Sådan sagde en af mine makedonske bekendte til mig, da jeg sidst var på vej til den makedonske hovedstad Skopje.

Han har ret. Det er helt overvældende at ankomme til den ny-kunstigt klassiske Skopje, dens lige findes vist ikke noget sted i verden.

Faktisk begynder det allerede, når man lander i Alexander den Store lufthavnen en halv times kørsel fra byen - og så straks ruller ud på Alexanders motorvej ind til byen. Der er flere store skilte, der venligt fortæller, at der er knap $700 \mathrm{~km}$ til Athen - her ad Alexander af Makedoniens motorvej. I årevis har makedonerne og grækerne skændtes om, hvem der har retten til at kalde sig Alexander den Stores efterkommere. Nu har de beslaglagt hans navn til at give den tilrejsende klar besked om, hvis han er.

En debat som kan virke noget høitflyvende - al den stund vi taler om en historisk person, der levede for mere end 2.300 år siden. Endnu værre er det, når striden handler om, hvem af grækerne og makedonerne, der har retten til at bruge navnet Makedonien. Den strid har varet i 20 år, og den har afholdt Makedonien fra at blive optaget i NATO og i realiteten også fra at komme tættere til EU, fordi Grækenland har blokeret for det.

Men det handler om identitetsopbygning, om efter Jugoslaviens opløsning at genfinde en makedonsk sjæl. Det er i hvert fald den begrundelse, den nuværende premierminister Nikola Gruevski brugte, da han satte det gigantiske kitschprojekt i gang i Skopje for nogle år siden.

Igennem de seneste år er centrum i den makedonske hovedstad blevet totalt ombygget.

Egentlig hed projektet Skopje 2014, men her i 2015 bygger de stadig. Der kommer hele tiden nye projekter til. Det gigantiske byggeri har omdannet hele Skopjes postkommunistiske nedslidte bykerne til en bizar blanding af antikke statuer af Alexander den Store og hans far Filip den Anden, tempellignende bygninger med søjler, retsbygning a la antikken, teater i centraleuropæisk 1900-tals udseende, museer, rytterstatuer, springvand, en triumfbue, hellige og lærde mænd på søjler som fx slaviske Kyrillos og

Anne Haubek er redaktør af 'Europa lige nu', DR P1 
gigantiske ortodokse katedral, som man ellers havde planlagt lige ved Skopjes gamle albanske bazar.

Men signalet var tydeligt, og det er et sindbillede på, hvor adskilt albanerne og makedonerne lever med hinanden i dag, og hvor dominerende det slavisk makedonske er i det politiske liv.

\section{Krigen i 2001}

Den seneste krig på europæisk jord -bortset fra krigen i Ukraine netop nu - var i 2001 i Makedonien. Albanske oprørere angreb makedonske militære styrker. Politisk, sproglig og økonomisk diskrimination fik bægeret til at flyde over. Men det var kort efter Kosovokrigen, og det internationale samfund i skikkelse af bl.a. EU var hurtig til at få en aftale på plads, Ohrid-fredsaftalen, der skulle sikre en bedre etnisk repræsentation. Ingen ønskede en gentagelse af hverken krigene i Bosnien eller Kosovo.

En del af Ohrid-aftalen er gennemført, en del er ikke, men rent formelt er den albanske repræsentation i den offentlige administration steget. Albanere er i højere grad repræsenteret i lokale administrationer, og loven sikrer, at der er undervisning på albansk på alle niveauer i uddannelsessystemet.

Imidlertid har der de seneste år i det daglige været stigende etniske og politiske spændinger mellem albanerne i Makedonien og deres slaviske landsmænd. Når jeg spørger mine makedonske og albanske venner om det, så siger de, at de lever sammen på arbejdspladser og uddannelsesinstitutioner, men når det handler om familierelationer og sociale forhold, så lever de to grupper stadig meget adskilt.

I 2012 oplevede makedonerne igen etniske uroligheder. I april 2012 blev fem slavisk makedonske fiskere fundet dræbt, og kort efter udførte myndighederne en storstilet politioperation i albansk dominerede områder, som resulterede $i$, at seks albanske makedonere blev arresteret, anklaget for mordene.

De blev alle seks idømt livsvarigt fængsel efter en meget lang og omdiskuteret retsproces, der foregik bag lukkede døre - og en stor del af bevisbyrden blev baseret på vidneudsagn fra personer, der var under vidnebeskyttelse.

Det fik de værste og mest voldelige uroligheder på daværende tidspunkt siden 2001 til at bryde ud, da tusindvis af vrede demonstranter gik på gaden for at protestere mod dommene og mod retsprocessen i 'Monstra-sagen.'

Det svarede det makedonske politi på ved efterfølgende at ransage en række albanske hjem, og seks albanere blev idømt helt op til tre års fængsel for at deltage $\mathrm{i}$ demonstrationerne. Det var en dom, som også var med til at forstærke de etniske spændinger, fordi mange albanere mente, at dommen var hårdere, netop fordi de var seks var albanere.

\section{Stabiliteten truet}

Makedonien befinder sig netop i disse uger og måneder i den dybeste politiske krise siden krigen i 2001, og den truer med at destabilisere hele landet. Oppositionen har i et år boykottet arbejdet i parlamentet i protest mod påstået valgsvindel ved parlamentsvalget for et år siden - et valg som også er blevet kritiseret af OSCE for uregelmæssigheder - og den højreorienterede og meget populistiske regering har resideret alene i regeringsbygningerne siden da.

Inden for de seneste måneder er det blevet oprullet, hvordan 20.000 mennesker i toppen af det makedonske samfund er blevet aflyttet - toppolitikere, regeringsfolk, udenlandske diplomater, 
journalister, skuespillere, osv. Lidt efter lidt er disse aflytninger blevet offentliggjort. Det er uklart, hvem der står bag aflytningerne, men det er oppositionslederen Zoran Zaev, der forløbende lader 'bomberne' springe.

Båndene afslører et retssystem, der er gennemsyret af korruption, og hvordan der udøves politisk pres på domstolene. For eksempel kan man på en lydfil høre to toppolitikere tale om, hvordan omkring 100 journalister bliver aflyttet. En anden lydfil dokumenterer valgsvindel fra lokalvalg i 2013, hvor slaviske makedonere, der bor i Albanien, blev udstyret med valgkort og midlertidig adresse i Makedonien og så kørt ind i landet og fulgt til stemmeboksene for at stemme på det regerende parti.

Premierminister Nikola Gruevski og regeringen afviser lydfilerne som falske og konstrueret af udenlandske efterretningstjenester - den græske eller den amerikanske - for at fremprovokere et regimeskifte.

\section{Yderligere eskalering}

I maj 2015 brød de alvorligste kampe siden 2001 ud i den albanskdominerede by Kumanovo, hvor omkring 18 mennesker mistede livet. Pludselig var der scener i gaderne, der sendte mindelser tilbage til krigene på Balkan i 1990'erne. Otte af de døde var makedonske politifolk, mens de øvrige formodes at være kosovoalbanere. Myndighedernes forklaring lød, at makedonsk politi havde afsløret en terrorgruppe, men meget hurtigt begyndte rygterne at løbe om, at kampene i Kumanovo i virkeligheden var orkestreret af den makedonske regering $i$ et forsøg på at fjerne fokus fra afsløringerne i aflytningsskandalen.

Det er ikke så ofte, begivenheder i Makedonien når de internationale medier, men denne gang har det været anderledes.
Pludselig igen har der været overskrifter om 'frygten for at krudttønden på Balkan skulle eksplodere igen'.

Det internationale samfund har handlet hurtigt. Ambassadører fra de store EU-lande indledte sammen med USA's ambassadør i Makedonien den første dialog med de makedonske toppolitikere kort efter kampene i Kumanovo, og nu er EU gået ind i konflikten mellem regering og opposition i en aktiv rolle.

EU's kommissær for europæisk naboskabspolitik og udvidelsesforhandlinger, Johannes Hahn, har efter lange forhandlinger både i Skopje og i Bruxelles fået parterne til at enes om at udskrive valg $\mathrm{i}$ april 2016. I skrivende stund er der dog stadig stor uenighed om, hvornår regeringen skal gå af for at give plads til de nødvendige reformer frem mod et valg. Det handler $\mathrm{fx}$ om at få lavet helt nye valglister for at undgå valgsvindel.

Desuden har EU heller ikke endnu i hvert fald - offentligt forholdt sig til de afsløringer, der er kommet frem i hele aflytningsskandalen. Det er massive anklager om korruption, der stadig bør undersøges til bunds af en retsinstans.

\section{Forholdet til EU}

Den nuværende krise har altså fået EU på banen i Makedonien igen.

Makedonien har ellers haft status som EU-kandidatland siden 2005, men de egentlige tiltrædelsesforhandlinger er ikke gået i gang. Landet har ikke gjort sig klar til det. EU udgiver en gang om året en 'fremskridtsrapport' om kandidatlandenes status, og i den seneste fra oktober 2014 bliver der fra EU's side talt med meget store og kritiske bogstaver om tilstandene. Det handler om stigende politisk indflydelse på statslige institutioner og om regeringskontrol med medier.

Fx kritiserer EU regeringen for at bruge 
offentlige midler til at reklamere for sig selv og noterer, at der mangler regulær uafhængig journalistik. EU anfører, at tilliden til statslige institutioner er dalende, der er grund til bekymring over et selektivt retsvæsen, og at partierne prioriterer egne interesser over nationale interesser. Alt sammen kritikpunkter der peger i den modsatte retning af et demokrati - og nærmere over i den autoritære eller 'illiberale' stat, som man kan se tydelige træk af andre steder i regionen.

Graden af engagement fra EU har været vigende de senere år i takt med, at andre problemstillinger har presset sig på i regionen og andre steder. Reformvenlige kræfter i Makedonien i dag taler om, at EU bør intervenere med en langsigtet støtteproces, der især skal hjælpe med en fundamental forandring af retssystem og offentlig administration.

Denne formelle EU-kritik bekræftes til fulde af de makedonske kilder, jeg selv taler med. Der er stor og begrundet frygt blandt journalister for at kritisere ledende politikere, og der er reelt meget få frie medier. De fleste tør ikke længere sige, hvad de mener.
Spørgsmålet om, hvor megen energi EU kommer til at lægge i Makedonien lige nu, er ubesvaret. Der skal gennemgribende reformer til - både på kort sigt og på lang sigt - hvis samfundet skal forandre sig.

Lige nu er fokus på hvilke reformer, der skal til, for at Makedonien kan gennemføre et frit og demokratisk parlamentsvalg til april 2016.

På lang sigt handler det om at forandre en kultur, der er grundlæggende korrupt, og lægge magten hos demokratisk valgte politikere og skabe et retfærdigt og upolitisk retssystem - i stedet for den klientilisme og mafia-lignende kultur, som præger store dele af det makedonske samfund i dag.

Lige nu er EU også udfordret af, at der stort set ikke findes uafhængige medier i Makedonien. Det kan gøre det nemmere for den nuværende regering at klare sig igennem krisen. Der er hårdt pres både fra regeringskontrollerede medier og fra russiske medier, som fastholder at hele aflytningsskandalen er orkestreret fra udlandet - ikke mindst USA, men også Grækenland bliver jævnligt nævnt som hemmelig aktør. 


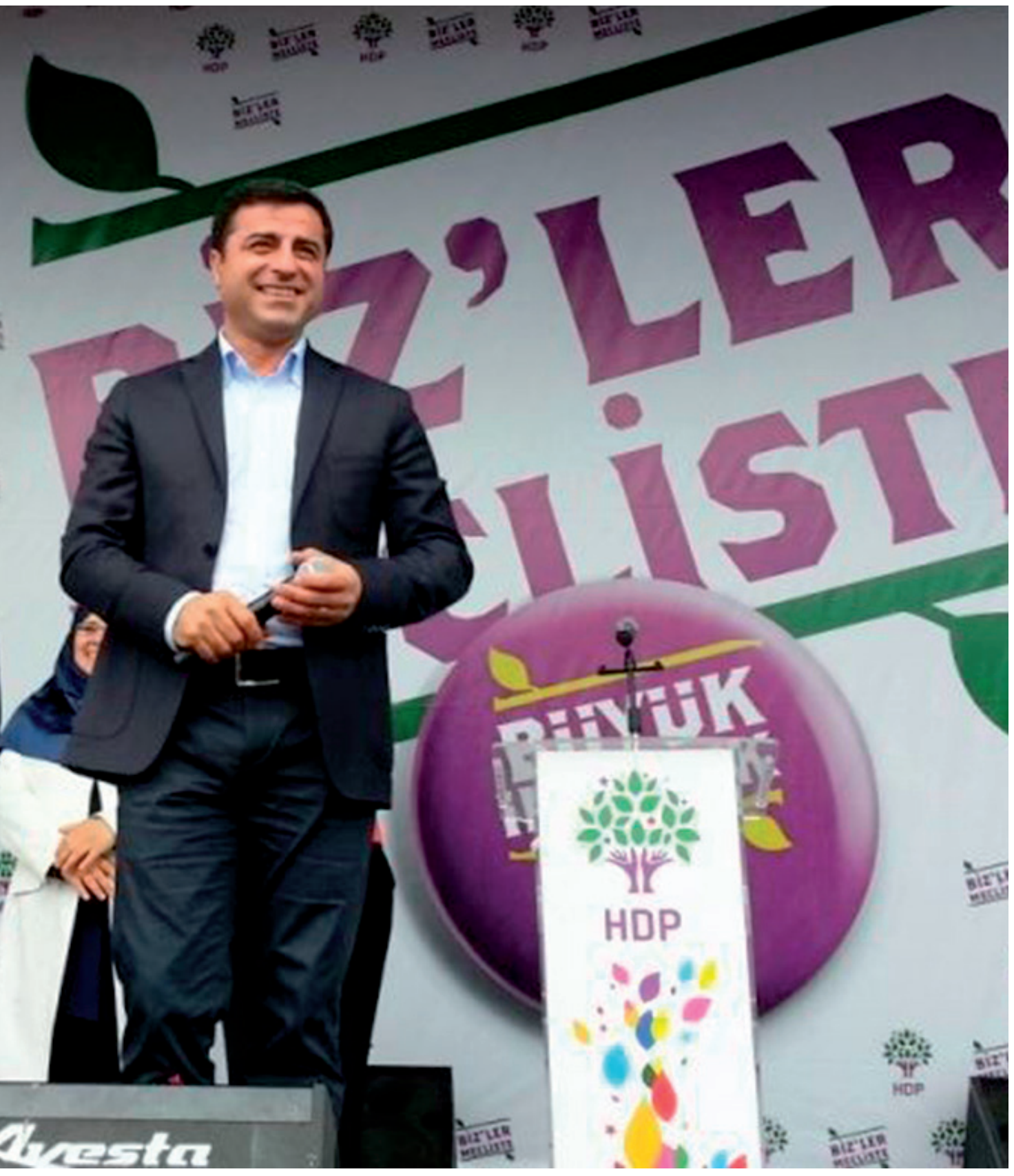

En tilfreds partileder Selahattin Demirtas efter valget, der for første gang gav det kurdiske parti sæde i det tyrkiske parlament.

FOTO: By Hilmi HacaloGlu, via Wikimedia Commons, 2015 